\title{
Effect of manufacturing process using superheated steam on the quality improvement of pickled radish product
}

\author{
Eunmi Kim*, Jeong-Ho Lim, Yun-Sang Choi, Ki-Hong Jeon \\ Korean Food Research Institute, Seongnam 13539, Korea
}

과열증기를 이용한 무우절임 제품의 제조공정 설정 및 품질 개선효과

\author{
김은미* · 임정호·최윤상·전기홍 \\ 한국식품연구원
}

\begin{abstract}
This study was conducted to develop radish as a food product for home meal replacement using superheated steam (SHS). Also, the change of quality characteristics was studied during their storage. The radish cuts were treated with SHS for $0,3,5$, and 7 min, respectively, followed by complete drying at $80^{\circ} \mathrm{C}$ for 6 hours. The results showed that radishes restored with mixed solution (drinking water:sugar:vinegar:salt=2:1:0.8:0.1) were harder than those restored with drinking water. All radishes were stored at 5,10 and $15^{\circ} \mathrm{C}$ for 56 days to investigate the changes of quality characteristics during the storage. Radishes in the control group, restored with drinking water and stored at $15^{\circ} \mathrm{C}$, were spoiled after 7 days of storage. The radish in the experimental group did not show any change in the water content; except an increase on the first day of storage. The hardness of radish decreased with an increase in the storage period. It was found that microbial growth was inhibited due to low $\mathrm{pH}$ of the mixed solution, in which radishes of the experimental group were immerse.
\end{abstract}

Key words : radish, home meal replacement, superheated steam, drying, restoration of water immersion

\section{서 론}

식품 산업에 있어서 가장 중요한 과제는 제품 유통기간 중의 안전성과 제품 본연의 품질을 유지한 상태로 유통기한 을 연장하는 것이다. 식품구매에 있어 급격히 까다로워지 는 소비자들의 요구와 엄격해지는 식품 규정들은 가공식품 에 안전성 확보는 물론 고품질 식품생산을 위한 새로운 가공법 개발을 요구하고 있다(1). 경제 성장과 함께 식문화 의 변화로 인해 위생적이며 기호성이 높은 식품에 대한 선호도가 증가하고 있음에도 불구하고 기존의 제품들은 이를 만족시키지 못하고 있는 실정이며, 새로운 가공기법 을 이용한 제품개발 및 품질개선을 할 수 있는 기술력 확보

*Corresponding author. E-mail : kem@kfri.re.kr Phone : 82-31-780-9287, Fax : 82-31-780-9059

Received 14 June 2017; Revised 9 August 2017; Accepted 15 August 2017.

Copyright (c) The Korean Society of Food Preservation. All rights reserved.
가 필요한 상황이다(2).

이와 관련하여 최소가공기술로 가장 많이 사용되고 있는 비가열 가공기술인 초고압 가공과 신속하고 경제적인 과열 증기(superheated steam, SHS) 가공이 있다(3-5). 초고압 가 공은 높은 압력을 이용한 비가열 살균 공정으로 저장기간을 연장하여 냉장유통 간편편이식 개발에 이용되고 있으며, 레토르트 살균에 적용되어 제품 품질 및 관능 저하를 억제 하는 기술이다. 과열증기 가공은 높은 온도의 수증기를 사 용한 순간 단시간 조리법으로 이용되어 전통적인 열처리에 의한 영양손실과 품질저하를 최소화하여 주로 열처리가 필요한 한식인 불고기, 갈비찜 및 삼계탕 편이식 개발에 응용되고 있다. 실제로 Seo 등(6)과 Choi 등(7)의 연구에서 과열증기와 초고압을 이용하여 위생적이고 우수한 품질의 식품을 생산할 수 있었다. 과열증기는 $100-400^{\circ} \mathrm{C}$ 의 고온의 수증기를 활용하여 미생물 살균, 탈취 및 비타민 C 산화, 지방 산패, 산소에 의한 갈변 현상 억제 등의 식품의 품질개 선 효과가 있는 가공 방법으로 보고되고 있다 $(8,9)$. 또한 식재료의 가열 및 조리시간을 단축시켜 고품질의 유통기한 
이 연장된 식자재를 개발하기 위한 방법으로 연구되고 있다 (10).

무(Raphanus sativus L.)는 십자화과에 속하는 한해살이 또는 두해살이 쌍떡잎식물로, 무는 고유의 향미와 독특한 맛을 가지고 있어 김치의 주재료 또는 부재료로 소비되기도 하며, 음식의 부재료로 오랫동안 사용되고 있다(11-13). 사 회발전에 맞추어 편의식을 제조하는 산업이 커지고 있으며 이에 따라 신선한 식자재의 수요가 증가하고 있다. 그러나 원 상태의 농산물과 달리 가공공정을 거친 식자재는 품질변 화로 인해 상품적인 가치가 떨어지게 된다(14). 편의식 식자 재로 유통되는 무 가공품으로는 무말랭이, 무짱아치 등이 있으며 염분함량이 높아 냉장상태에서 비교적 유통기간이 높은 제품들이다. 하지만 비빔밥용 무와 같이 저염이나 신 선 상태의 식자재로서의 무에 대한 유통기한 연장 연구는 거의 진행된바가 없다. 따라서 본 연구에서는 과열증기라 는 가공기술을 이용하여 기존 제품보다는 유통안전성이 있으며 품질이 개선된 편의식 식자재로서의 무 가공품을 제조하고자 실시하였다.

\section{재료 및 방법}

\section{시료의 제조}

편의식 식자재 가공공정 개발을 위한 전반적인 제조공정 은 Fig 1 과 같다.

무게가 일정한 생무 $(1.5-2 \mathrm{~kg})$ 를 음용수로 3 번 세척한 다음, 일정한 크기(약 $60 \mathrm{~mm} \times 12 \mathrm{~mm} \times 12 \mathrm{~mm}$ )로 세절하고 과열증기기(DC Quto, QF-5200C, Naomoto, Osaka, Japan)를 이용하여 예비가열한 후 열풍건조 $\left(80^{\circ} \mathrm{C}\right)$ 를 실시하여 무건 조물을 제조하였다. 생무의 예비가열(preheating)은 과열증 기 조건이 내부온도 $250^{\circ} \mathrm{C}$, 증기온도 $370^{\circ} \mathrm{C}$ 조건에서 가열 시간을 0-7분으로 달리하여 외피의 변화가 없는 조건으로 결정하였다(Fig. 1). 이러한 과열증기 조건은 예비실험을 통하여 무의 표면에 열처리에 의해 타는 현상이 나타나지 않도록 미리 실험하여 설정 하였다.

예비가열을 거친 무는 바로 건조하였으며 건조조건은 $80^{\circ} \mathrm{C}$ 의 온도에서 열풍건조(dry oven, HSC-150, Hanam, Korea)를 실시하였다. 다음단계로 건조한 무를 조미액 침지 하여 복원하였다. 음용수로 침지한 것을 대조군으로 하고, 2 종류의 조미용액에 침지한 것을 실험군으로 정하여 건조 된 무를 침지하였다. 무의 복원을 위하여 사용한 조미용액 은 2종류로 $\mathrm{A}$ 용액(음용수:설탕:식초:소금 $=2: 1: 1: 0.25$ )과 $\mathrm{B}$ 용액 (음용수:설탕:식초:소금 $=2: 1: 0.8: 0.1$ )을 이용하여 건조 무를 복원하고 조미특성이 침투하도록 하였다.

조미액에 침지한 무를 과열증기 내부온도 $180^{\circ} \mathrm{C}$, 증기온 도 $350^{\circ} \mathrm{C}$ 에서 5 분간 2 차 가열을 실시하였다. 2 차 가열된 시제품을 약 $300 \mathrm{~g}$ 씩 $\mathrm{PE}$ 포장지에 담은 다음 밀봉하였으며
밀봉한 시제품을 $100^{\circ} \mathrm{C}$ 이하의 열탕에 10-30초간 통과시켜 포장지 외피의 오염물을 제거한 다음 포장지외피의 물기를 제거하여 완성하였다.

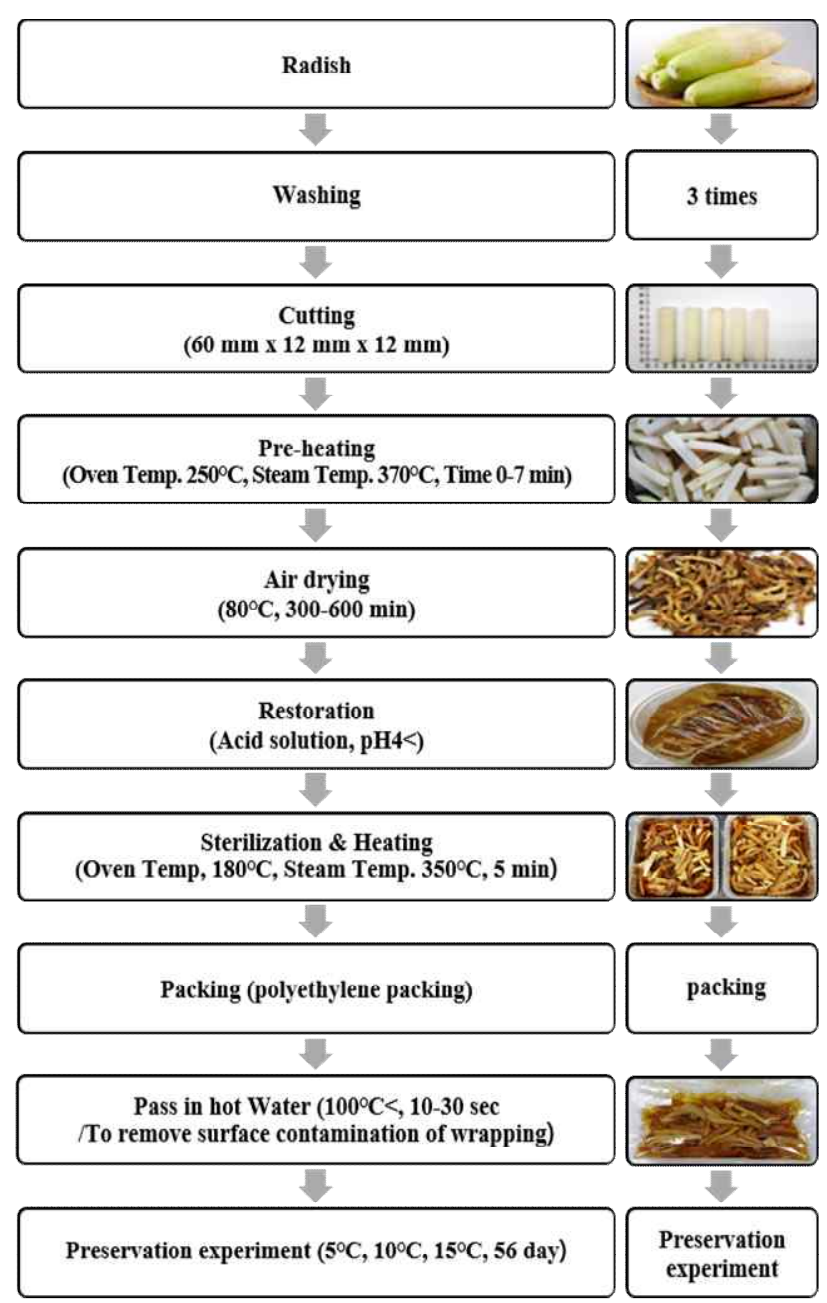

Fig. 1. Manufacturing process of radish product.

\section{저장 중 품질변화}

Fig. 1 의 과정으로 제조한 시제품을 $\mathrm{PE}$ 포장하여 $5^{\circ} \mathrm{C}, 1$ $0^{\circ} \mathrm{C}$ 및 $15^{\circ} \mathrm{C}$ 에서 56 일간 저장하면서 7 일 간격으로 품질변화 를 조사하였다. 동일한 공정에서 음용수를 이용하여 복원 한 시료를 대조군으로 설정하여 비교실험을 진행하였다.

\section{수분함량, 수분활성도 및 색도}

저장중의 품질변화로 수분함량은 $\mathrm{AOAC}(15)$ 의 표준분 석법에 준하여 $105^{\circ} \mathrm{C}$ 상압가열건조법으로 측정하였다. 수 분활성도는 Labmaster-aw(Labmaster-aw, Novasina SG, Lachen, Switzaerland)를 이용하여 측정하였다. 색도는 색차 계(CM-3500d, Konica Minolta Sensing, Tokyo, Japan)를 이 용하여 측정하고 이를 Hunter Lab Scale에 의한 L(lightness), $\mathrm{a}$ (redness) 및 $\mathrm{b}$ (yellowness) 값으로 나타내었다. 


\section{조직감}

무 가공품의 조직감은 Texture analyzer(TA-XT2, Stable Micro Systems Ltd., Godalming, UK)를 이용하여 지름 3 $\mathrm{mm}$ 인 aluminium cylinder probe(pretest speed: $1 \mathrm{~mm} / \mathrm{s}$, posttest speed: $10 \mathrm{~mm} / \mathrm{s}$, test speed: $2 \mathrm{~mm} / \mathrm{s}$ )로 압착시켰을 때 hardness를 측정하였으며, 10회 반복 측정 후 평균치를 계산하였다.

\section{$\mathrm{pH}$}

무 가공품의 $\mathrm{pH}$ 는 무가공품 시료 $10 \mathrm{~g}$ 을 취하여 $90 \mathrm{~mL}$ 의 증류수에 희석한 후 Whatman filter paper(Whatman filter paper No. 2, GE healthcare life science, Buckinghamshire, $\mathrm{UK}$ )로 여과하여 $\mathrm{pH}$ meter(Orion 3-star plus $\mathrm{pH}$ Benchtop meter, Orion Research Inc., MA, USA)를 이용하여 측정하였 다.

\section{총균수 측정}

무 가공품의 총균수 측정은 $3 \mathrm{M}$ 건조필름 $\left(P^{2}\right.$ trifilm ${ }^{\mathrm{TM}}$ plate, $3 \mathrm{M}$ Co., St. Paul, MN, USA)을 이용하여 진행하였으 며, $35^{\circ} \mathrm{C}$ 배양기에서 48 시간 배양 후 $25-250$ 개의 집락을 형성한 평판을 택하여 $\mathrm{g}$ 당 집락수를 계산하였다.

\section{통계분석}

분석결과는 평균값 \pm 표준편차(mean $\pm \mathrm{SD}$ )로 표시하였으 며 통계 처리는 Statistics Package for the Social Science (SPSS, Ver. 18.0 for windows, SPSS Inc., Chicago, IL, USA) 프로그램을 이용하여 one-way ANOVA를 실시하였으며, 처리구간 유의성 검증은 Tukey's test로 유의 수준 $\mathrm{p}<0.05$ 에 서 실시하였다.

\section{결과 및 고찰}

\section{전처리 가열조건의 설정}

세절 무의 전처리 조건으로 과열증기기(SHS, superheated steam oven)로 예비가열을 실시하였다. 예비가열은 급격한 수분이탈로 세절무의 초기수분을 감소시켜 건조시간을 단 축하고 예비가열로 인한 탈취효과와 초기오염을 낮출 것으 로 생각되었다. 과열증기기의 조건은 내부온도 $250^{\circ} \mathrm{C}$, 스팀 온도 $370^{\circ} \mathrm{C}$ 로 설정한 뒤, 각각 $0,3,5$ 및 7 분의 시간동안 무를 처리한 후 무게 변화와 총균수의 변화를 살펴보았다. 그 결과를 Table 1 에 나타내었다. 무게의 변화는 7 분 처리시 세절무의 무게는 처음무게의 $88.3 \%$ 이었으며, 가장자리가 검게 그을린 것을 볼 수 있었으나 3 분과 5 분 처리한 무의 경우 외피가 그을린 흔적이 보이지 않았다. 과열증기를 3 분간 처리한 무는 외피에 수분이 많이 함유되어 있고 무게 감량이 $1.2 \%$ 정도로 과열증기를 처리효과가 없는 것으로
생각되었다. 세절무를 5 분 과열증기 처리하였을 경우 외관 의 변화가 없고 무게변화는 $5.2 \%$ 정도 발생하는 것으로 조 사되었다. 총균수의 변화에서도 초기 원료 무에서는 4.16 $\log \mathrm{CFU} / \mathrm{g}$ 정도 검출되었으나 과열증기 3 분 가열에서도 균이 검출되지 않아서 초기오염을 제거하는데 효과가 있는 것으로 조사되었다. 따라서 과열증기기 전처리 조건은 내 부온도(heater) $250^{\circ} \mathrm{C}$, 과열증기온도(steam) $370^{\circ} \mathrm{C}$ 에서 5 분 가열하는 것으로 설정하였다. 과열증기는 끓는점 이상의 온도를 갖는 수증기로서 고온의 증기를 이용할 경우, 살균, 탈취 등의 부수적인 효과를 높일 수 있다는 장점이 있다. 또한 일반 열기건조에 비해 빠른 건조속도를 나타내며 다른 건조 공정과의 조합이 용이하다는 장점도 있다 $(6,7,10,22)$.

Table 1. Changes in weight and microbiological analysis of radishes heated for different duration at the same SHS temperature (heater $250^{\circ} \mathrm{C}$, steam $370^{\circ} \mathrm{C}$ )

\begin{tabular}{ccccc}
\hline Heating time (min) & 0 & 3 & 5 & 7 \\
\hline Weight changes (\%) & 100 & $98.2 \pm 2.5$ & $94.8 \pm 3.4$ & $88.3 \pm 2.8$ \\
Microorganism (log CFU/g) & $4.16 \pm 0.30$ & $\mathrm{ND}^{1)}$ & $\mathrm{ND}$ & $\mathrm{ND}$ \\
\hline
\end{tabular}

${ }^{1)}$ Not detected.

과열증기 내부온도(heater: $250^{\circ} \mathrm{C}$; steam: $370^{\circ} \mathrm{C}$ )의 조건 에서 $0,3,5$ 및 7 분간 처리한 무를 $80^{\circ} \mathrm{C}$ 의 온도에서 1-6 시간 동안 열풍건조하며 무의 품질변화를 검토하였다. 원 료 무를 세절한 후, 과열증기로 $0,3,5$ 및 7 분간 전 처리한 다음 $80^{\circ} \mathrm{C}$ 열풍 건조한 원료무의 외관변화는 Fig. 2 와 같다.

건조시간에 따른 무의 수분함량 변화를 Table 2에 나타내 었다. 건조시간은 무 시료의 중량변화가 거의 없는 시간을 건조 종점으로 하였다. 열처리한 모든 시료가 6시간 이후에 수분함량의 변화가 크지 않은 것으로 보아 평형 수분 함량 에 다다른 것으로 판단되었다. 또한 5 시간 이하 건조한 경우 같은 건조 시간 내에서는 과열증기 처리 시간이 길수록 수분함량이 적은 것을 볼 수 있었다 $(\mathrm{p}<0.05)$. 전체적으로 과열증기로 예비가열을 실시한 경우, 원료무 외피의 급격 한 수분증발로 무외피가 수축하는 것을 확인할 수 있었으며 외피의 급격한 수분 손실로 건조시간을 단축할 수 있었다. 과열증기로 $3-5$ 분 예비가열한 세절무는 $80^{\circ} \mathrm{C}$ 에서 6시간내 에 모두 건조되는 것을 확인하였다 $(\mathrm{p}<0.05)$.

과열증기 전처리한 무의 열풍건조 후 수분활성도 결과를 Fig. 3에 나타내었다. 과열증기 전처리한 무의 초기 수분활 성도는 0.97(7분)-0.99(3분)의 범위로 나타났으며, 열풍건 조 시간이 길어질수록 감소하여 최종 수분활성도는 $0.37(7$ 분)-0.42(5분)의 범위로 측정되었다. 무의 수분활성도는 열 풍건조 4시간까지는 큰 차이를 보이지 않다가 4시간 이후 에 급격히 감소하는 경향을 나타내었다 $(\mathrm{p}<0.05) . \mathrm{Kim}$ 등 (10)은 호밀-밀 혼합 빵의 저장 4 일 이후, 빵의 외부가 건조 되면서 상대습도가 낮아져 빵 내부의 수분이 증발하여 수분 

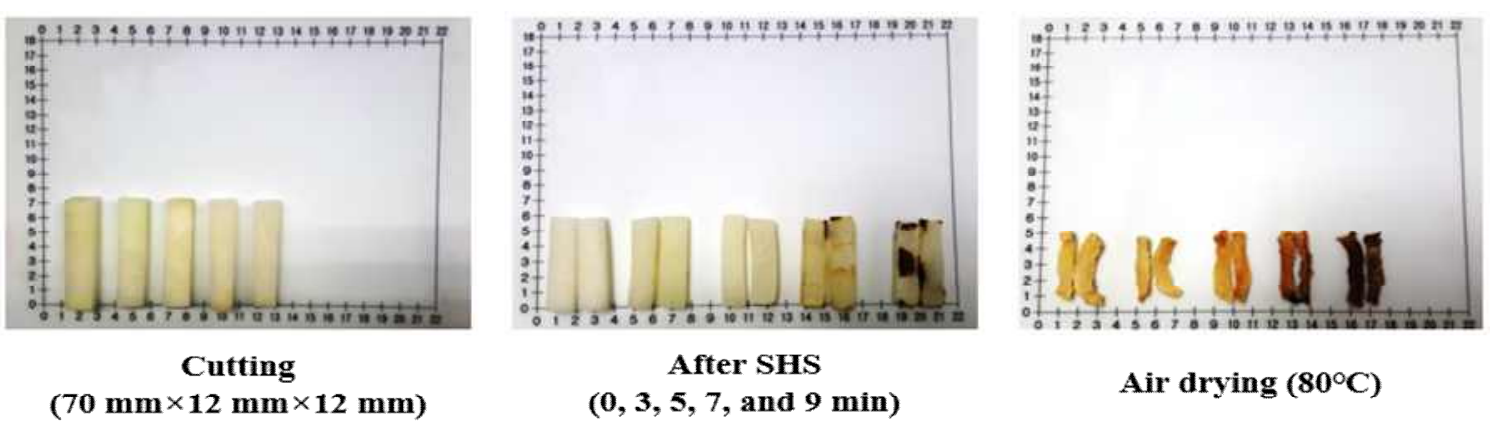

Air drying $\left(80^{\circ} \mathrm{C}\right)$

Fig. 2. Changes in appearance of radish pieces after treatment with superheated steam treatment (heater: $250^{\circ} \mathrm{C}$; steam: $370{ }^{\circ} \mathrm{C}$ ), heating time: $0,3,5,7$, and $9 \mathrm{~min}$, respectively, and air drying $\left(80^{\circ} \mathrm{C}, 6 \mathrm{~h}\right)$.

Table 2. Moisture content (\%) of radishes with different SHS pre-heating and duration of drying at $80^{\circ} \mathrm{C}$

\begin{tabular}{ccccccc}
\hline Heating $^{1)}$ time (min) & \multicolumn{7}{c}{ Drying time (h) } \\
\cline { 2 - 7 } & 1 & 2 & 3 & 4 & 5 & 6 \\
\hline 0 & $94.54 \pm 0.06^{\mathrm{a} 2)}$ & $92.24 \pm 0.14^{\mathrm{a}}$ & $87.44 \pm 0.25^{\mathrm{a}}$ & $65.66 \pm 0.32^{\mathrm{a}}$ & $39.44 \pm 0.25^{\mathrm{a}}$ & $30.88 \pm 0.21^{\mathrm{a}}$ \\
3 & $92.87 \pm 0.06^{\mathrm{ab}}$ & $89.47 \pm 0.30^{\mathrm{b}}$ & $73.71 \pm 0.96^{\mathrm{b}}$ & $59.20 \pm 0.33^{\mathrm{b}}$ & $26.84 \pm 0.14^{\mathrm{b}}$ & $15.91 \pm 0.04^{\mathrm{b}}$ \\
5 & $89.63 \pm 0.05^{\mathrm{b}}$ & $84.09 \pm 0.49^{\mathrm{c}}$ & $76.19 \pm 0.12^{\mathrm{b}}$ & $63.59 \pm 0.28^{\mathrm{ab}}$ & $26.13 \pm 1.18^{\mathrm{b}}$ & $15.85 \pm 0.16^{\mathrm{b}}$ \\
7 & $83.51 \pm 0.13^{\mathrm{c}}$ & $82.62 \pm 0.19^{\mathrm{c}}$ & $74.11 \pm 0.53^{\mathrm{b}}$ & $49.82 \pm 0.37^{\mathrm{c}}$ & $22.84 \pm 0.34^{\mathrm{c}}$ & $16.30 \pm 0.15^{\mathrm{b}}$ \\
\hline
\end{tabular}

${ }^{1)}$ Heating temperature: $250^{\circ} \mathrm{C}$, Steam temperature: $370^{\circ} \mathrm{C}$.

${ }^{2}$ Values with different lowercase superscripts in the same column are significantly differently by Tukey's test $(\mathrm{p}<0.05)$.

활성도가 감소되었다고 보고하였다. 무가 건조되면서 상대 습도가 낮아져 무 내부의 수분이 증발하면서 수분활성도가 감소된 결과로 생각된다.

과열증기로 예비가열한 원료무의 건조시간에 따른 색도 변화는 Table 3에 나타내었다. 가열시간에 따른 $\mathrm{L}$ 값의 변화 는 예비가열 조건에 따라 변화가 크지 않은 것으로 조사되 었으나 $\mathrm{a}$ 값과 $\mathrm{b}$ 값의 변화는 큰 것으로 나타났다. 과열증기 5 분과 7분 처리시 3-4시간 건조했을 때 감소하였고, 6시간 건조 후에는 오히려 증가하였다. 반면에 3 분 간 예비가열

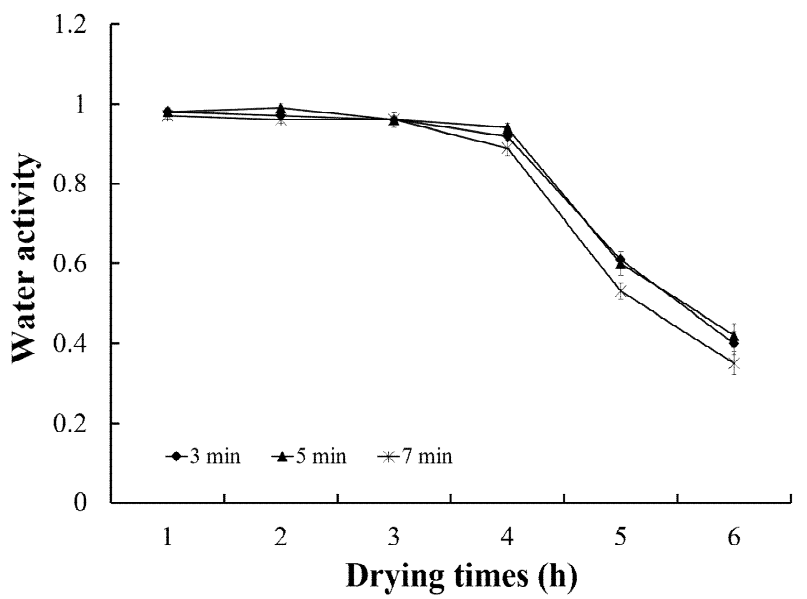

Fig. 3. Water activity of radishes after different SHS pre-heating and duration of drying at $80^{\circ} \mathrm{C}$.
처리한 무의 경우는 2 시간 이상 건조할수록 $\mathrm{L}$ 값이 감소하 였다. Redness를 나타내는 a 값은 과열증기를 3,5 및 7 분 처리한 무 모두에서 건조시간에 따라 증가하였다. 이는 건 조되면서 무가 흰색에서 갈색으로 변화한 것을 반영한 것으 로 생각된다. Yellowness를 나타내는 $\mathrm{b}$ 값 역시 $\mathrm{a}$ 값과 마찬 가지로 증가하는 경향을 나타내었다( $\mathrm{p}<0.05)$.

\section{건조 무의 복원 및 조미공정의 설정}

세절무에 조미특성을 가미하고 조직을 복원하고자 건조 한 세절무를 조미용액에 침지하였다. 조미액은 세종류로 음용수, 식초와 소금함량을 달리한 용액 $\mathrm{A}$ (음용수:설탕:식 초:소금=2:1:1:0.25), 용액 $\mathrm{B}($ 음용수:설탕:식초:소금=2:1:0.8:0.1) 이다.

과열증기(heater: $250^{\circ} \mathrm{C}$; steam: $370^{\circ} \mathrm{C}$ )로 5 분간 처리한 무를 $80^{\circ} \mathrm{C}$ 에서 6 시간 건조한 세절무를 음용수, 조미액 $\mathrm{A}$ 와 $\mathrm{B}$ 에 각각 침지시킨 후 48 시간 동안 냉장고 $\left(0^{\circ} \mathrm{C}\right)$ 저장하여 충분히 복원한 다음 각각의 조미액을 제거 한 다음 기호도 를 조사한 결과는 Table 4 와 같다. 음용수를 이용하여 복원 한 세절무의 조직감에 대한 기호도는 9점 만점 중 3.5점으로 낮았으며 $(\mathrm{p}<0.05)$, 바로 조직감이 물러지는 현상을 나타내 었다. 조미액으로 복원한 경우 조직이 단단하여 형태유지 가 안정적이고 조직감에 대한 기호도가 음용수로 복원한 무보다 높은 것으로 나타났다. 용액 $\mathrm{A}$ 로 복원한 경우, 용액 $\mathrm{B}$ 보다 식초함량이 높아 신맛이 강한 것으로 평가되어 전반 
Table 3. Hunter color values of radishes with different SHS pre-heating and duraton of drying at $80^{\circ} \mathrm{C}$

\begin{tabular}{|c|c|c|c|c|c|c|c|}
\hline \multirow{2}{*}{\multicolumn{2}{|c|}{ Heating $^{11}$ time (min) }} & \multicolumn{6}{|c|}{ Drying time (h) } \\
\hline & & 1 & 2 & 3 & 4 & 5 & 6 \\
\hline \multirow{3}{*}{0} & $\mathrm{~L}$ & $63.09 \pm 2.64^{\mathrm{ab} 2)}$ & $68.89 \pm 1.03^{\mathrm{a}}$ & $67.03 \pm 1.01^{\mathrm{a}}$ & $67.31 \pm 1.07^{a}$ & $60.65 \pm 1.04^{b}$ & $58.68 \pm 1.02^{\mathrm{b}}$ \\
\hline & $\mathrm{a}$ & $-1.62 \pm 0.09^{d}$ & $-1.79 \pm 0.04^{d}$ & $1.59 \pm 0.09^{c}$ & $2.82 \pm 0.34^{\mathrm{c}}$ & $6.42 \pm 0.48^{\mathrm{b}}$ & $11.86 \pm 1.17^{\mathrm{a}}$ \\
\hline & $b$ & $8.96 \pm 1.13^{\mathrm{e}}$ & $13.03 \pm 0.54^{\mathrm{d}}$ & $22.01 \pm 1.71^{c}$ & $21.00 \pm 1.05^{\mathrm{c}}$ & $24.52 \pm 0.84^{\mathrm{bc}}$ & $29.23 \pm 1.03^{\mathrm{a}}$ \\
\hline \multirow{3}{*}{3} & $\mathrm{~L}$ & $63.27 \pm 2.89^{b}$ & $70.19 \pm 1.02^{\mathrm{a}}$ & $66.35 \pm 1.25^{\mathrm{ab}}$ & $65.46 \pm 4.28^{\mathrm{ab}}$ & $59.81 \pm 0.69^{c}$ & $58.17 \pm 0.98^{\circ}$ \\
\hline & $\mathrm{a}$ & $-1.64 \pm 0.15^{\mathrm{d}}$ & $-1.77 \pm 0.05^{\mathrm{d}}$ & $1.52 \pm 0.13^{\mathrm{c}}$ & $2.74 \pm 0.37^{\mathrm{c}}$ & $6.08 \pm 1.00^{\mathrm{b}}$ & $11.89 \pm 1.07^{\mathrm{a}}$ \\
\hline & $\mathrm{b}$ & $8.45 \pm 0.59^{\mathrm{d}}$ & $12.99 \pm 0.49^{c}$ & $22.18 \pm 1.21^{\mathrm{b}}$ & $20.57 \pm 1.35^{b}$ & $24.68 \pm 1.29^{\mathrm{ab}}$ & $29.17 \pm 1.14^{\mathrm{a}}$ \\
\hline \multirow{3}{*}{5} & $\mathrm{~L}$ & $63.38 \pm 2.65^{b}$ & $63.12 \pm 2.28^{b}$ & $64.32 \pm 1.37^{\mathrm{ab}}$ & $59.89 \pm 1.47^{c}$ & $64.80 \pm 0.44^{\mathrm{ab}}$ & $67.72 \pm 0.65^{\mathrm{a}}$ \\
\hline & $\mathrm{a}$ & $-1.15 \pm 0.08^{d}$ & $1.40 \pm 0.36^{\mathrm{c}}$ & $2.03 \pm 0.90^{c}$ & $2.64 \pm 0.06^{\mathrm{c}}$ & $6.22 \pm 0.44^{b}$ & $9.58 \pm 1.29^{\mathrm{a}}$ \\
\hline & $\mathrm{b}$ & $11.21 \pm 1.16^{\mathrm{d}}$ & $16.89 \pm 1.95^{\mathrm{c}}$ & $18.72 \pm 0.68^{c}$ & $23.53 \pm 1.23^{b}$ & $24.30 \pm 1.11^{\mathrm{b}}$ & $33.99 \pm 1.30^{\mathrm{a}}$ \\
\hline \multirow{3}{*}{7} & $\mathrm{~L}$ & $61.77 \pm 1.41^{b}$ & $61.93 \pm 0.86^{b}$ & $59.63 \pm 1.10^{\mathrm{bc}}$ & $57.57 \pm 0.97^{c}$ & $60.33 \pm 1.96^{b}$ & $65.83 \pm 1.57^{\mathrm{a}}$ \\
\hline & $\mathrm{a}$ & $1.58 \pm 0.17^{\mathrm{c}}$ & $1.84 \pm 0.27^{\mathrm{c}}$ & $5.22 \pm 0.16^{b}$ & $6.39 \pm 0.34^{b}$ & $7.20 \pm 1.06^{b}$ & $10.24 \pm 0.46^{\mathrm{a}}$ \\
\hline & $\mathrm{b}$ & $20.13 \pm 1.71^{c}$ & $21.64 \pm 1.11^{\mathrm{c}}$ & $26.21 \pm 1.57^{b}$ & $26.25 \pm 0.79^{b}$ & $27.02 \pm 1.69^{b}$ & $32.95 \pm 1.10^{\mathrm{a}}$ \\
\hline
\end{tabular}

${ }^{1)}$ Heating temperature: $250^{\circ} \mathrm{C}$, Steam temperature: $370^{\circ} \mathrm{C}$.

${ }^{2)}$ Values with different lowercase superscripts in the same row are significantly differently by Tukey's test $(\mathrm{p}<0.05)$.

적인 기호도가 5.1점으로 나타났으며, 용액 $\mathrm{B}$ 를 이용하여 복원하였을 때에는 6.2점으로 나타났으나 두 용액 종류에 따른 유의적 차이는 없었다. 따라서 건조한 세절무의 조미 액으로 전반적인 기호도 점수가 높은 용액 $\mathrm{B}$ 로 결정하였다.

\section{살균 및 저장 중 품질변화}

과열증기 내부온도(heater) $250^{\circ} \mathrm{C}$, 과열증기(steam) $370^{\circ} \mathrm{C}$ 의 조건에서 5 분간 처리한 무를 $80^{\circ} \mathrm{C}$ 건조조건에서 6 시간 건조한 다음, 조미액(B)을 이용하여 복원한 후 과열증기(오 븐온도 $180^{\circ} \mathrm{C}$, 증기온도 $350^{\circ} \mathrm{C}$ )에서 5 분간 2 차 가열을 실시 한 다음 $\mathrm{PE}$ 포장지에 $300 \mathrm{~g}$ 씩 담은 다음 밀봉하였다. 밀봉 한 시제품을 $100^{\circ} \mathrm{C}$ 이하의 열탕에 10-30 초간 통과시켜 포장지 외피의 오염물을 제거한 다음 포장지 외피의 물기를 제거하였다. 이러한 공정을 모두 마친 시제품을 $5^{\circ} \mathrm{C}, 10^{\circ} \mathrm{C}$ 및 $15^{\circ} \mathrm{C}$ 에서 56 일간 저장하며 7 일 간격으로 품질변화를 알아보았다. 동일한 공정에서 조미용액 대신 음용수로 복 원한 것을 대조구로 하였으며 대조군에 대한 실험결과는 Table 5 에 나타내었다. 대조구에서 $15^{\circ} \mathrm{C}$ 에서 7 일간 저장한

Table 4. Preference test with different immersion solution

\begin{tabular}{|c|c|c|c|}
\hline Preference ${ }^{1)}$ & Drinking water & Solution $A^{2)}$ & Solution $\mathrm{B}^{3)}$ \\
\hline Overall preference & $3.5 \pm 0.2^{\mathrm{a} 4)}$ & $5.1 \pm 0.2^{b}$ & $6.2 \pm 0.4^{b}$ \\
\hline Comments & Weak texture & $\begin{array}{l}\text { Good texture, } \\
\text { strong acidity }\end{array}$ & Good texture \\
\hline
\end{tabular}

\footnotetext{
1)9-Point hedonic scale.

${ }^{2)}$ Solution $\mathrm{A}=$ Drinking water $:$ Sugar $:$ Vinegar $:$ Salt $=2: 1: 1: 0.25$

${ }^{3}$ Solution $\mathrm{B}=$ Drinking water $:$ Sugar $:$ Vinegar : Salt $=2: 1: 0.8: 0.1$

${ }^{4)}$ Values with different lowercase superscripts in the same row are significantly different by Tukey's test $(\mathrm{p}<0.05)$.
}

무는 $\mathrm{pH}$ 가 증가 하였고, $\mathrm{L}$ 값이 감소하였으며, 미생물도 가장 많이 증식하였다 $(\mathrm{p}<0.05)$. 저장온도 $15^{\circ} \mathrm{C}$ 에서 7 일간 저장한 복원된 무시료가 가장 낮은 외관 품질을 나타냈으며 심하게 부패하여 기호도 중 향, 맛 및 씹힘성에 대한 검사는 진행하지 못했으며, 7일 이후에는 모두 부패하여 분석을 중단하였다.

\section{저장 중 수분함량 변화}

조미액에 침지한 복원한 무의 저장 중 수분함량은 Table 6에 나타내었다. 실험군은 저장기간 동안 일정한 경향의 수분함량은 나타나지 않았으나, $5^{\circ} \mathrm{C}, 10^{\circ} \mathrm{C}$ 및 $15^{\circ} \mathrm{C}$ 에 저장하 였을 때 모두 초기보다 수분함량이 증가하였다( $<<0.05)$. 음 용수로 불린 대조군의 경우, 실험군보다 모두 수분함량이 낮았으며, 7 일 저장 후 모두 수분함량이 감소하였다.

\section{저장 중 색도 변화}

조미액에 침지한 복원한 무의 저장 중 색도변화는 Table 7에 나타내었다. 대조군의 경우 7일 저장 후 저장온도가 높을수록 lightness를 나타내는 L 값이 감소하였고, 붉은 정도를 나타내는 a 값이 증가하였다. 실험군에서는 전반적 으로 저장기간에 따라 일정한 경향을 보이지 않고 불규칙한 값을 나타내었는데 이는 건조과정중에 수축된 무가 조미액 에 의해 복원했으나 불규칙한 외관을 가지고 있기 때문이라 고 생각된다. 그러나 저장 초기와 마지막 날을 비교해보면L 값은 감소한 반면, $\mathrm{a}$ 값과 $\mathrm{b}$ 값은 증가한 것으로 보인다. 저장기간이 길어질수록 무가 갈변되어 붉은 색과 노란색이 강해졌으며, $10^{\circ} \mathrm{C}$ 에 저장했을 때 a 값이 1.48 로 가장 높았고 $15^{\circ} \mathrm{C}$ 에 저장했을 때 b 값이 17.63 으로 가장 크게 나타났다. 
Table 5. Physicochemical properties, preference and microbiological analysis of radishes restored with drinking water during storage

\begin{tabular}{|c|c|c|c|c|c|}
\hline \multicolumn{2}{|c|}{ Analysis Item } & 0 day & 7 day $\left(5^{\circ} \mathrm{C}\right)$ & 7 day $\left(10^{\circ} \mathrm{C}\right)$ & 7 day $\left(15^{\circ} \mathrm{C}\right)$ \\
\hline \multicolumn{2}{|c|}{ Moisture content (\%) } & $49.59 \pm 0.34$ & $44.84 \pm 1.01$ & $45.89 \pm 0.48$ & $44.14 \pm 0.27$ \\
\hline \multicolumn{2}{|r|}{$\mathrm{pH}$} & $5.08 \pm 0.02^{\mathrm{b} 2)}$ & $5.63 \pm 0.06^{\mathrm{ab}}$ & $5.80 \pm 0.04 \mathrm{ab}$ & $6.75 \pm 0.01^{\mathrm{a}}$ \\
\hline \multicolumn{2}{|c|}{ Hardness (kg) } & $2.89 \pm 1.04$ & $2.77 \pm 1.12$ & $2.93 \pm 1.14$ & $0.78 \pm 1.13$ \\
\hline \multirow{3}{*}{$\begin{array}{l}\text { Hunter } \\
\text { color } \\
\text { value }\end{array}$} & $\mathrm{L}$ & $66.78 \pm 1.07^{\mathrm{a}}$ & $63.28 \pm 0.43^{\mathrm{ab}}$ & $62.53 \pm 0.34^{b}$ & $60.21 \pm 0.29^{c}$ \\
\hline & $\mathrm{a}$ & $-0.61 \pm 0.05$ & $-0.19 \pm 0.01$ & $-0.30 \pm 0.04$ & $-0.05 \pm 0.03$ \\
\hline & $\mathrm{b}$ & $18.00 \pm 0.64$ & $16.78 \pm 0.11$ & $16.36 \pm 0.24$ & $16.12 \pm 0.15$ \\
\hline \multicolumn{2}{|c|}{ Microorganism (log CFU/g) } & $3.13 \pm 0.01^{\mathrm{c}}$ & $6.64 \pm 0.05^{b}$ & $6.54 \pm 0.03^{b}$ & $8.33 \pm 0.56^{\mathrm{a}}$ \\
\hline \multirow{5}{*}{ Preference ${ }^{1)}$} & Appearance & $6.60 \pm 2.19^{\mathrm{a}}$ & $6.42 \pm 1.07^{\mathrm{a}}$ & $5.87 \pm 0.95^{\mathrm{a}}$ & $4.24 \pm 1.51^{b}$ \\
\hline & Flavor & $6.60 \pm 1.14^{\mathrm{a}}$ & $5.49 \pm 1.55^{\mathrm{ab}}$ & $5.04 \pm 1.78^{\mathrm{b}}$ & - \\
\hline & Taste & $4.80 \pm 1.79$ & $4.45 \pm 0.67$ & $4.34 \pm 1.93$ & - \\
\hline & Chewiness & $6.60 \pm 2.30$ & $6.41 \pm 1.61$ & $6.29 \pm 1.24$ & - \\
\hline & Overall preference & $5.40 \pm 2.30^{\mathrm{a}}$ & $5.11 \pm 2.46^{\mathrm{a}}$ & $5.14 \pm 1.89^{\mathrm{a}}$ & $4.11 \pm 1.20^{\mathrm{b}}$ \\
\hline
\end{tabular}

${ }^{1)} 7$-Point hedonic scale.

${ }^{2)}$ Values with different lowercase superscripts in the same row are significantly differently by Tukey's test $(\mathrm{p}<0.05)$

Table 6. Change in moisture contents of restored radishes during storage at different temperatures

(unit: \%)

\begin{tabular}{|c|c|c|c|c|c|c|c|c|c|c|}
\hline & \multicolumn{9}{|c|}{ Storage period (day) } & \multirow{2}{*}{ F-value } \\
\hline & 0 & 7 & 14 & 21 & 28 & 35 & 42 & 49 & 56 & \\
\hline $5^{\circ} \mathrm{C}$ & $62.90 \pm 0.35^{\mathrm{cl})}$ & $64.45 \pm 0.37^{\mathrm{bc}}$ & $65.68 \pm 0.35^{b}$ & $65.71 \pm 0.04^{b}$ & $65.62 \pm 0.00^{b}$ & $65.28 \pm 0.16^{b}$ & $66.55 \pm 0.30^{\mathrm{ab}}$ & $67.49 \pm 0.06^{\mathrm{a}}$ & $64.95 \pm 0.08^{b c}$ & $59.121^{* * *}$ \\
\hline $10^{\circ} \mathrm{C}$ & $62.90 \pm 0.35^{\mathrm{c}}$ & $66.82 \pm 1.75^{\mathrm{b}}$ & $67.21 \pm 0.05^{\mathrm{a}}$ & $65.23 \pm 0.04^{\mathrm{b}}$ & $65.07 \pm 0.01^{\mathrm{b}}$ & $65.67 \pm 0.74^{b}$ & $65.87 \pm 0.01^{\mathrm{b}}$ & $64.86 \pm 0.06^{b}$ & $65.47 \pm 0.05^{\mathrm{b}}$ & $7.355^{* *}$ \\
\hline $15^{\circ} \mathrm{C}$ & $62.90 \pm 0.35^{\mathrm{c}}$ & $62.98 \pm 0.23^{c}$ & $66.44 \pm 0.04^{\mathrm{b}}$ & $67.34 \pm 0.08^{\mathrm{a}}$ & $63.94 \pm 0.17^{\mathrm{bc}}$ & $65.28 \pm 0.01^{\mathrm{b}}$ & $64.62 \pm 0.11^{b}$ & $65.02 \pm 0.04^{\mathrm{b}}$ & $64.47 \pm 0.12^{\mathrm{b}}$ & $163.548^{* * *}$ \\
\hline
\end{tabular}

${ }^{1)}$ Values with different lowercase superscripts in the same row are significantly differently by Tukey's test $(\mathrm{p}<0.05)$.

Table 7. Change in Hunter color values of radishes restored during storage at different temperatures

\begin{tabular}{|c|c|c|c|c|c|c|c|c|c|c|c|}
\hline & & \multicolumn{9}{|c|}{ Storage period (day) } & \multirow{2}{*}{ F-value } \\
\hline & & 0 & 7 & 14 & 21 & 28 & 35 & 42 & 49 & 56 & \\
\hline \multirow{3}{*}{$5^{\circ} \mathrm{C}$} & $\mathrm{L}$ & $63.64 \pm 1.73^{\text {abl) }}$ & $67.71 \pm 1.56^{\mathrm{a}}$ & $65.15 \pm 1.03^{\mathrm{a}}$ & $64.20 \pm 2.61^{\mathrm{ab}}$ & $61.50 \pm 1.76^{b}$ & $61.93 \pm 0.38^{b}$ & $56.98 \pm 0.10^{c}$ & $63.48 \pm 1.90^{\mathrm{ab}}$ & $59.50 \pm 1.75^{b}$ & $7.735^{* \star}$ \\
\hline & $\mathrm{a}$ & $-0.60 \pm 025^{\mathrm{c}}$ & $0.53 \pm 0.12^{\mathrm{ab}}$ & $0.90 \pm 0.13^{\mathrm{a}}$ & $0.85 \pm 0.20^{\mathrm{a}}$ & $0.62 \pm 0.08^{\mathrm{ab}}$ & $0.61 \pm 0.23^{\mathrm{ab}}$ & $0.35 \pm 0.18^{b}$ & $0.20 \pm 0.11^{b}$ & $0.25 \pm 0.18^{b}$ & $12.982^{* * *}$ \\
\hline & $\mathrm{b}$ & $13.62 \pm 0.82^{c}$ & $18.25 \pm 0.25^{\mathrm{a}}$ & $16.38 \pm 0.01^{b}$ & $16.77 \pm 0.52^{\mathrm{b}}$ & $16.26 \pm 1.44^{b}$ & $15.93 \pm 1.24^{\mathrm{bc}}$ & $19.52 \pm 2.04^{\mathrm{a}}$ & $17.45 \pm 0.25^{\mathrm{ab}}$ & $13.86 \pm 0.84^{\mathrm{c}}$ & $6.798^{* *}$ \\
\hline \multirow{3}{*}{$10^{\circ} \mathrm{C}$} & $\mathrm{L}$ & $63.64 \pm 1.73^{b}$ & $62.07 \pm 2.35^{b}$ & $68.96 \pm 0.99^{\mathrm{a}}$ & $61.23 \pm 0.48^{\mathrm{b}}$ & $60.45 \pm 1.58^{\mathrm{bc}}$ & $61.35 \pm 0.37^{\mathrm{b}}$ & $62.60 \pm 0.98^{\mathrm{b}}$ & $64.67 \pm 0.44^{b}$ & $57.14 \pm 1.93^{c}$ & $10.910^{* *}$ \\
\hline & $\mathrm{a}$ & $-0.60 \pm 0.25^{\mathrm{e}}$ & $1.56 \pm 0.04^{\mathrm{bc}}$ & $0.33 \pm 0.09^{\mathrm{d}}$ & $2.43 \pm 0.11^{\mathrm{a}}$ & $0.76 \pm 0.18^{\mathrm{d}}$ & $1.30 \pm 0.42^{\mathrm{c}}$ & $1.85 \pm 0.05^{\mathrm{b}}$ & $1.08 \pm 0.00^{\mathrm{d}}$ & $1.48 \pm 0.23^{\mathrm{c}}$ & $40.052^{* * *}$ \\
\hline & $\mathrm{b}$ & $13.62 \pm 0.82^{b}$ & $17.07 \pm 0.79^{\mathrm{a}}$ & $17.23 \pm 0.28^{\mathrm{a}}$ & $17.10 \pm 0.37^{\mathrm{a}}$ & $15.20 \pm 0.73^{\mathrm{ab}}$ & $17.76 \pm 1.56^{\mathrm{a}}$ & $16.94 \pm 0.27^{\mathrm{a}}$ & $18.31 \pm 0.82^{\mathrm{a}}$ & $16.41 \pm 1.97^{\mathrm{a}}$ & $4.001^{*}$ \\
\hline \multirow{3}{*}{$15^{\circ} \mathrm{C}$} & $\mathrm{L}$ & $63.64 \pm 1.73^{\mathrm{a}}$ & $61.28 \pm 0.44^{\mathrm{ab}}$ & $61.48 \pm 1.29^{\mathrm{ab}}$ & $59.74 \pm 0.13^{\mathrm{ab}}$ & $57.28 \pm 0.03^{\mathrm{b}}$ & $61.97 \pm 1.36^{\mathrm{ab}}$ & $57.73 \pm 0.51^{b}$ & $62.33 \pm 0.83^{\mathrm{a}}$ & $60.28 \pm 1.34^{\mathrm{ab}}$ & $8.416^{* *}$ \\
\hline & $\mathrm{a}$ & $-0.60 \pm 0.26^{\mathrm{d}}$ & $2.53 \pm 0.08^{\mathrm{a}}$ & $1.31 \pm 0.08^{\mathrm{c}}$ & $2.59 \pm 0.95^{\mathrm{a}}$ & $0.85 \pm 0.00^{c}$ & $1.09 \pm 0.23^{\mathrm{c}}$ & $2.51 \pm 0.05^{\mathrm{a}}$ & $1.88 \pm 0.30^{\mathrm{bc}}$ & $1.31 \pm 0.34^{\mathrm{c}}$ & $15.348^{* * *}$ \\
\hline & $\mathrm{b}$ & $13.62 \pm 0.82^{b}$ & $16.82 \pm 0.21^{\mathrm{ab}}$ & $17.91 \pm 0.14^{\mathrm{a}}$ & $18.48 \pm 0.57^{\mathrm{a}}$ & $15.22 \pm 0.38^{\mathrm{ab}}$ & $17.92 \pm 0.25^{\mathrm{a}}$ & $16.74 \pm 0.59^{\mathrm{ab}}$ & $18.56 \pm 1.89^{\mathrm{a}}$ & $17.63 \pm 2.00^{\mathrm{a}}$ & $5.234^{*}$ \\
\hline
\end{tabular}

${ }^{1)}$ Values with different lowercase superscripts in the same row are significantly differently by Tukey's test $(\mathrm{p}<0.05)$

Lee 등(17)의 연구에서 무의 열처리 온도가 높아질수록 갈변도가 증가하여 a 값이 증가하는 경향을 보였는데, 본 연구에서 산침지 후 복원한 무의 저장온도가 높아질수록 a 값이 증가하는 것과 유사한 경향을 나타내었다.

\section{저장 중 조직감 변화}

조미액에 침지한 복원한 무의 저장 중 조직감 변화는 Fig. 4에 나타내었다. 조미액으로 침지한 세절무의 외관상 수축정도가 개별적으로 차이가 있어 시료에서도 편차가 크게 조사되었다. 그러나 조미액 침지한 실험군은 저장기 
간이 길어질수록 경도가 점차 감소하는 경향을 보였고, 1 $0^{\circ} \mathrm{C}$ 와 $15^{\circ} \mathrm{C}$ 에 저장했을 때 저장 초기보다 경도가 크게 감소 하는 것을 확인하였다. 이러한 결과는 Son 등(18)의 연구에 서 순무 피클을 35 일간 저장하면서 경도를 분석했을 때 경도가 점차 감소하는 것과 유사함을 확인하였다. 참고로 음용수로 침지한 대조군의 경우 초기 경도값은 $2.89 \mathrm{~kg}$ 이었 으나, $15^{\circ} \mathrm{C}$ 에서 7 일간 저장하였을 때 무가 부패하여 조직이 물러져 경도가 $0.78 \mathrm{~kg}$ 로 크게 감소하였다(Table 5).

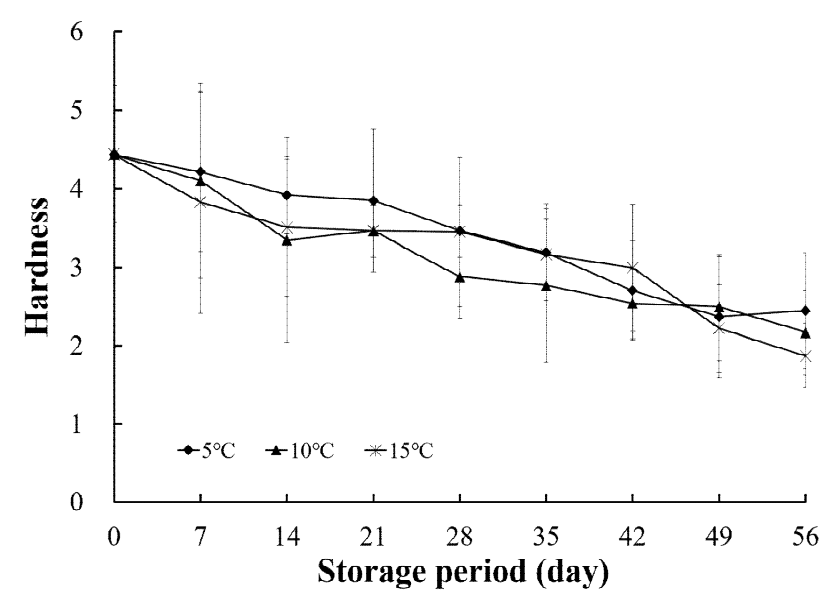

Fig. 4. Changes in hardness of radishes restored at different temperatures.

\section{저장 중 $\mathrm{pH}$ 변화}

조미액에 침지한 복원한 무의 저장 중 $\mathrm{pH}$ 변화는 Fig. 5 에 나타내었다. 대조군의 경우 저장 7일 후 세 가지 온도 모두에서 $\mathrm{pH}$ 가 증가하였는데, 과실의 경우 유기산 분해로 인한 것으로 알려져 있다(19). 실험군의 경우에는 8 주의 저장 기간 동안 온도에 따른 $\mathrm{pH}$ 변화는 크게 나타나지 않았 으나 저장 8 주째에 감소하는 경향을 보였다. 과실의 호흡으 로 인하여 $\mathrm{pH}$ 가 증가하는 경향을 보이지만 실험군은 $\mathrm{pH}$ 가 낮은 조미액을 이용한 복원과 진공포장 등의 요인이 복합적 으로 작용하여 큰 변화가 나타나지 않은 것으로 판단되었 다.

\section{저장 중 미생물 변화}

음용수로 불린 대조군의 무의 저장 중 총균수는 초기 미생물이 $3.13 \log \mathrm{CFU} / \mathrm{g}$ 이었으나, $5^{\circ} \mathrm{C}$ 와 $10^{\circ} \mathrm{C}$ 에서 7 일간 저장한 후 각각 6.64 및 $6.54 \log \mathrm{CFU} / \mathrm{g}$ 으로 증가하였고, $15^{\circ} \mathrm{C}$ 에서 저장한 경우에는 부패하여 $8.33 \log \mathrm{CFU} / \mathrm{g}$ 까지 미생물이 증가하였다(Table 5). 그러나 조미액을 이용한 실 험군은, 저장기간 동안 모든 저장 온도 $\left(5^{\circ} \mathrm{C}, 10^{\circ} \mathrm{C}\right.$ 및 $\left.15^{\circ} \mathrm{C}\right)$ 에 서 미생물이 검출되지 않았다. 이는 가열증기로 높은 온도 처리로 인해 오염군을 일부 제거 할 수 있으나 완전제거가 어려움을 알 수 있었다. 가열증기이외로 $\mathrm{pH}$ 가 낮은 조미액 침지가 미생물을 증식을 추가적으로 억제하는데 효과가
있을 알 수 있었다. 이는 조미액으로 인해 $\mathrm{pH}$ 값이 모든 저장온도에서 $\mathrm{pH}$ 4이하로 미생물의 영양원이 될 수 있는 신선편이 채소류의 범위 4.9-6.5(20,21)보다 낮기 때문이라 고 생각되었다.

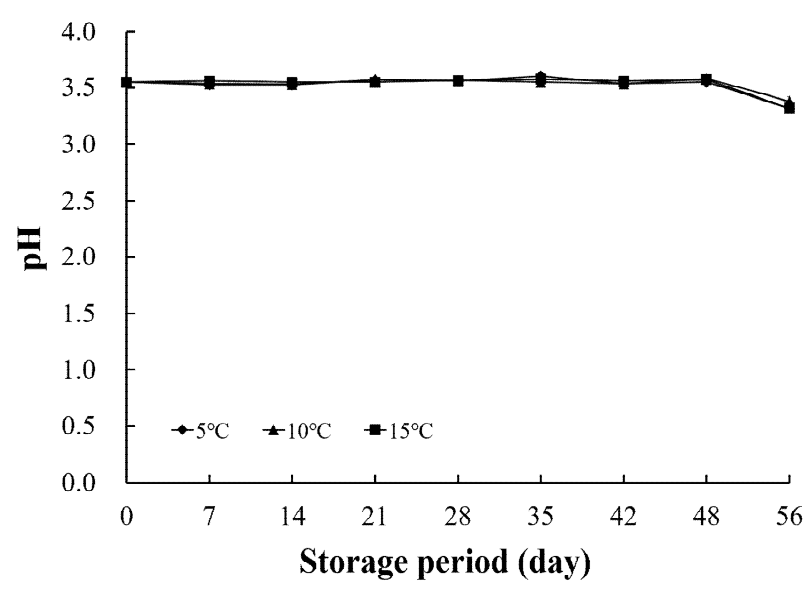

Fig. 5. Changes in $\mathrm{pH}$ of radishes restored at different temperatures.

\section{요 약}

본 연구는 과열증기(superheated steam, SHS) 기술을 이 용하여 높은 품질의 편의식 식자재로서의 무를 제조하고, 제조한 무의 저장 중 품질변화를 알아보기 위해 수행하였 다. 적당히 자른 무를 1 차 과열증기(오븐온도 $250^{\circ} \mathrm{C}$, 증기온 도 $370^{\circ} \mathrm{C}$ )에서 각각 $0,3,5$ 및 7 분간 처리한 후, $80^{\circ} \mathrm{C}$ 에서 6 시간동안 완전히 건조 하였다. 본 연구 결과, 혼합용액(음 용수:설탕:식초:소금 $=2: 1: 0.8: 0.1)$ 에서 복원한 무가 음용수 만으로 복원한 무에 비해 좀 더 단단하였다. 5,10 및 $15^{\circ} \mathrm{C}$ 에 서 56 일간 저장한 모든 무를 품질변화를 측정하였다. 물로 복원하고 $15^{\circ} \mathrm{C}$ 에 저장한 대조구 무는 저장 7 일만에 부패하 였다. 실험구 무는 저장 1 일을 제외하고, 수분 함량에 변화 가 없었다. 저장기간이 증가함에 따라 무의 단단한 조직감 이 감소하였다. 혼합용액으로 복원한 무는 낮은 $\mathrm{pH}$ 로 인해 미생물 성장이 억제되었다. 따라서 SHS의 사용과 혼합용액 을 이용한 복원은 손쉽게 무 제품을 개발할 수 있었다.

\section{감사의 글}

본 연구는 2015년 농림축산식품부 고부가가치식품기술 개발사업(과제번호: 315061-3)과 2016년 한국식품연구원 주요사업의 지원에 의해 이루어진 것이며 이에 감사드립니 다. 


\section{References}

1. Park JY, Na SY, Lee YJ (2010) Present and future of non-thermal food processing technology. Food Science and Industry, 43, 2-20

2. Kim YJ, Lee EJ (2007) Application of hydrostatic pressure techniques on the meat products. Korean J Food Science and Industry, 40, 36-40

3. Park JY (2009) High-hydrostatic pressure pasteurization. Food Industry, 210, 9-23

4. Lee SJ, Kim CJ, Cho YJ (2000) Hydration and texture characteristics of brown rice treated with superheated steam process. J Korean Soc Food Sci Nutr, 29, 1190-1194

5. Seo SH, Kim EM, Kim YB, Cho EK, Woo HJ, Lee MA (2014) Quality improvement of Galbijjim using superheated steam and high hydrostatic pressure. J Korean Soc Food Sci Nutr, 43, 1423-1430

6. Seo SH, Kim EM, Kim YB, Cho EK, Woo HJ (2014) A study on development of Samgyetang using superheated steam and high hydrostatic pressure. Korean J Food Cook Sci, 30, 183-192

7. Choi Y, Oh JH, Bae IY, Cho EK, Kwon DJ, Park HW, Yoon S (2013) Changes in quality characteristics of seasoned soy sauce treated with superheated steam and high hydrostatic pressure during cold storage. Korean J Food Cook Sci, 29, 387-398

8. Oh JH, Yoon S, Choi Y (2014) The effect of superheated steam cooking condition on physico-chemical and sensory characteristics of chicken breast fillets. Korean J Food Cook Sci, 30, 317-324

9. Kim OS, Lee DH, Chun WP (2008) Eco-friendly drying technology using superheated steam. Korean Chem Eng Res, 46, 258-273

10. Kim BC, Hwang JY, Wu HJ, Lee SM, Cho HY, Yoo YM, Shin HH, Cho EK (2012) Quality changes of vegetables by different cooking methods. Korean J Culinary Res, 18, 40-53
11. Park JE, Kim MJ, Jang MS (2009) Optimization of ingredient mixing ratio for preparation of Chinese radish (Raphanus sativus L.) Jam. J Korean Soc Food Sci Nutr, 38, 235-243

12. Korean Society of Food and Cookery Science (2003) Dictionary of food cookery science. Kyomunsa, Seoul, Korea, p 100-101

13. Kim GH (1999) Optimization of minimally processed white radish for Kkakttugi preparation. Korean J Soc Food Sci, 15, 633-638

14. Sun SH, Kim SJ, Kim GC, Kim HR, Yoon KS (2011) Changes in quality characteristics of fresh-cut produce during refrigerated storage. Korean J Food Sci Technol, 43, 495-503

15. AOAC (1990) Official Methods of Analysis. Association of Official Analytical Chemists, Washington DC, USA, p 17, p 37, p 440

16. Kim MY, Chun SS (2009) Changes in shelf-life, water activity, and texture of rye-wheat mixed bread with naturally fermented raisin extract and rye sourdough during storage. Korean J Food Cook Sci, 25, 170-179

17. Lee SH, Hwang IG, Lee YR, Joung EM, Jeong HS, Lee HB (2009) Physicochemical characteristics and antioxidant activity of heated radish (Raphanus sativus L.) extracts. J Korean Soc Food Sci Nutr, 38, 490-495

18. Son EJ, Oh SH, Heo OS, Kim MR (2003) Physicochemical and sensory characteristics of turnip pickle added with chitosan during storage. J Korean Soc Food Sci Nutr, 32, 1302-1309

19. Kim GH, Cho SD, Kim DM (1999) Quality evaluation of minimally processed asian pears. Korean J Food Sci Technol, 31, 1523-1528

20. Jo IH, Kim HS, Kim GM, Kim JS, Kim GC (2012) Effects of packaging method on the quality of blanched Namul during storage. Korean J Food Preserv, 9, 328-336

21. Lund BM (1992) Ecosystems in vegetable foods. J Appl Microbiol, 73, 115-126 